\section{Franco-Japanese plan mounted}

THE French deep-sea submersible, Nautile, designed to reach a depth of 6,000 metres with three scientists aboard, has behaved "beautifully" in its first trials in the Mediterranean, according to its test-pilots. Thus all augurs well so far for Nautile's real business this summer, the intended investigation of the deep-sea trenches off Japan, where in the south the Philippine plate, and in the north the Pacific plate, plunge under the continental Eurasian plate on which Japan is sitting.

According to the French co-director of the project, Xavier le Pichon of the University of Paris VII, Nautile will first carry out a seven-day trial run in the Puerto Rico trench at 6,000 metres, but there will be little time there for research. But in Japan in June and July, Nautile should make possible some unique geological observations on ane of the most active subduction regions in the world. And quite apart from the geotectonics, which are believed to be threatening a magnitude- 8 earthquake close to Tokyo in the near future, Nautile will be searching for subduction-zone analogues of the "vent communities" of sub-ocean animals discovered by the US submersible Alvin at spreading centres in the Pacific.

There are already indications, in the form of observations of up-welling mud from Japanese trenches, that there may be vents in the subduction zones, le Pichon says. Evidence was presented at the American Geophysical Union meeting in December of dense communities of tube worms and clams recovered by Alvin along the Oregon-Washington subduction complex. Bottom waters there, at a depth of 2,036 metres, are rich in methane, $\mathrm{Dr}$ Erwin Suess of Oregon State University reported, and the chemistry suggests processes involving methane oxidation.

Thus the phenomena that Nautile will be looking for are quite different from those in spreading centres, where hot sulphur-rich waters drive anoxic benthic communities. In the case of subduction zones, the processes seem likely to involve the extrusion of relatively cool pore waters from sediments rich in organic debris.

Geologically, one of the most important tasks of the Kaiko (Japanese for "trench") Franco-Japanese collaboration with Nautile will be to place a tilt-meter and seismometer, both Japanese-designed, at a depth of 2,500-3,000 metres near the Bonin ridge. This volcanic arc runs south-west of Tokyo, and ends on the landward side in the Izu peninsula - which is resisting subduction under Japan. It is a release in the stresses in this zone that most threatens the Tokyo region with major earthquakes, and the instruments to be placed by Nautile are designed to help predict movements (with the national earthquake prediction network, see Nature 312, 500; 1984).

But M. le Pichon describes the work to be done in placing these instruments as somewhat difficult - involving using Nautile to drill post-holes in the rock and an oceanographic "first", so nobody is yet entirely certain that the exercise will be successful.

Other work to be done by Nautile includes the direct observation of the subduction of two seamounts, one of them as big as Mt Fuji and already half-digested by the Japan trench, and a study of sediment deformation in the highly-sedimented

\section{NASA}

Washington

A PERPETUAL aircraft is being planned in the United States. The National Aeronautics and Space Administration (NASA) will shortly award $\$ 375,000$ for a feasibility study of a novel high-altitude atmospheric sensing vehicle, called the Carbon Dioxide Observation Platform System (CO-OPS). The novelty is that the unmanned aircraft would be given very long endurance by means of microwave power beamed up from ground stations.

As the project is still very much up in the air, nobody wants to appear too closely committed to it. Fred Koomanoff of the Department of Energy's carbon dioxide research programme says the idea for $\mathrm{CO}$ OPS was volunteered by Charles Guttman at NASA's Marshall Space Flight Center in Alabama. Guttman, however, when asked about the CO-OPS concept, said "there is no concept". NASA is simply following up on a Department of Energy study on the use of space for research on carbon dioxide in the atmosphere.

Koomanoff speculates that a long-en-
BRITAIN has withdrawn from the Ocean Drilling Project (ODP), because money for the annual subscription of $£ \mathbf{2 . 5}$ million could not be found in time for the January deadline. The only hope now is that, with appropriate juggling of accounts and perhaps some arm twisting, the United Kingdom could rejoin from next October.

Canada, France and West Germany have already joined ODP and Japan has said that it will join from next October; the project is run by the Joint Oceanographic Institutions and is administered at Texas A \& M University. ODP is the successor to the Deep Sea Drilling Project and involves a new ship known variously as "JOIDES Resolution" or the Sedco/BP 471, now completing its "shakedown" voyage.

For more than a year, the UK Natural Environment Research Council (NERC),

\title{
Perpetual plane in prospect
}

Nankai trough, where the Philippine plate meets the Eurasian plate.

Planning for the expedition began a decade ago, according to $M$. le Pichon. Operating costs for the two months' observation (some $£ 2$ million) will be divided equally between France and Japan. The construction costs of Nautile, borne by the French oceanographic agency the Institut Francais de Recherche Pour l'Exploitation de la Mer (IFREMER, formerly CNEXO), are estimated at "tens of millions" of pounds. With a diving capability of 6,000 metres, the vessel should be able to reach some 97 per cent of the oceans' deepest waters, it is claimed.

Robert Walgate

\section{Ocean Drilling Project setback}

durance craft flying at $60,000-70,000$ feet could be the best way of obtaining some atmospheric data; unlike balloons or manned aircraft, it could stay in nearly the same place for long periods. CO-OPS might measure atmospheric aerosols, concentration of carbon dioxide and trace gases in the atmosphere and obtain temperature and pressure profiles. CO-OPS could also observe land and sea ice and measure albedo. Military use is possible.

Some at NASA are sceptical about the use of microwave power, however, on the grounds that safety considerations could be limiting. Nevertheless, NASA's bid for proposals virtually rules out solar power and chemical energy for CO-OPS because of weight considerations, while low-cost phased-array transmitter technology "appears feasible"'.

Potential contractors are reminded that CO-OPS would be a low-cost project using proven technology, to fly in perhaps 5 or 6 years' time. The closing date for proposals was 30 November 1984.

Tim Beardsley together with the Department of Education and Science, has been trying to persuade the Department of Energy and members of the oil industry to top up NERC's contribution to reach the full subscription. A spokesman for NERC acknowledged that they had been successful in raising funds but that an unspecified gap still remains. It is hoped that, by deferring payment of the subscription until October, NERC can meet ODP's financial requirements. In principle, all British scientists should now come off the ODP committees but it is hoped that, if NERC can juggle its accounts (which would probably require Treasury approval - a commodity notorjously hard to acquire), a letter of intent could be sent that would permit some level of UK involvement in the interim.

Philip Campbell 